\title{
On the genus Neocladia Perkins, 1906 (Hymenoptera: Encyrtidae), with description of two new species
}

\author{
O роде Neoclada Perkins, 1906 (Hymenoptera: Encyrtidae) \\ с описанием Авух новых видов
}

\author{
Vladimir A. Trjapitzin ${ }^{1} \&$ Serguei V. Triapitsyn ${ }^{2}$ \\ B.A. Тряпищын ${ }^{1}$, С.В. Тряпицын ${ }^{2}$
}

\footnotetext{
${ }^{1}$ Do vostrebovania, Post Office 129344 (ulitsa Letchika Babushkina, 7), Moscow, Russia.

1 До востребования, п/о 129344 (ул. Лётчика Бабушкина, 7), Москва, Россия.

${ }^{2}$ Entomology Research Museum, Department of Entomology, University of California, Riverside, California, 92521, USA.
}

KEY WORDS: Hymenoptera, Encyrtidae, Neocladia, taxonomy, synonymy, key, Myanmar, Vietnam.

КЛЮЧЕВЫЕ СЛОВА: Hymenoptera, Encyrtidae, Neocladia, таксономия, синонимия, определитель, Мьянма, Вьетнам.

ABSTRACT: A diagnosis of the encyrtid (Hymenoptera: Encyrtidae) genus Neocladia Perkins, 1906 in the broad sense (reflecting the new generic synonymies proposed here) is given. Anagyrodes Girault, 1915, syn.n., Carabunia Waterston, 1928, syn.n., Elijahia Girault, 1928, syn.n., Paracladella Girault, 1920, syn.n., and Schillerana Girault, 1932, syn.n. are treated as junior subjective synonyms of Neocladia. A key to females of the species in these synonymized former genera and their synopsis (comprising 24 taxa) are provided. Neocladia korotjaevi V. Trjapitzin \& S. Triapitsyn, sp.n. from Vietnam and $N$. mikhailovi $\mathrm{V}$. Trjapitzin \& S. Triapitsyn, sp.n. from Myanmar (= Burma) are described and illustrated. Twenty-one new combinations are proposed: N. baethei (Girault, 1922), comb.n., N. dei (Girault, 1922), comb.n., N. gigantea (Girault, 1915), comb.n., N. maxima (Girault, 1915), comb.n., $N$. odacon (Walker, 1838), comb.n., and N. punctaticeps (Girault, 1928), comb.n. (all from Anagyrodes); N. angulimaculata (Xu \& He, 2003), comb.n., N. bicoloripes (Hayat, 2003), comb.n., N. dilatata (Girault, 1932), comb.n., N. gigantica (Subba Rao, 1973), comb.n., N. longimarginalis (Subba Rao, 1973), comb.n., N. madhukari (Mani \& Kaul, 1973), comb.n., N. myersi (Waterston, 1928), comb.n., $N$. orientalis (Subba Rao, 1971), comb.n., N. poeta (Girault, 1928), comb.n., N. waterstoni (Subba Rao, 1971), comb.n., and N. zora (Hayat, 2003), comb.n. (all from Carabunia); N. calicutana (Hayat, 2003), comb.n., N. giorgionei (Girault, 1932), comb.n., $N$. globosa (Girault, 1920), comb.n., and N. uttara (Hayat, 2003), comb.n. (all from Paracladella). Neocladia perkinsi Subba Rao, 1971, stat. rev., is reinstated in Neocladia (from Anagyrodes). A lectotype is designated for $N$. punctaticeps. Information on the known host associations of the genus is provided.
PЕЗЮМЕ. В статье дан диагноз рода Neoclada Perkins, 1906 в широком его понимании (отражающем предложенные здесь родовые синонимы). Anagyrodes Girault, 1915, syn.n., Paracladella Girault,1920, syn.n., Carabunia Waterston, 1928, Elijahia Girault, 1928, syn.n., и Schillerana Girault, 1932 трактуются как младшие субъективные синонимы рода Neoclada. Составлена определительная таблица смок видов Neoclada s.lato и приведён синопсис 24 описанных видов. Описаны и проиллюстрированы Neocladia korotjaevi V.Trjapitzin et S.Triapitsyn, sp.n. из Мьянмы (=Бирма). Предложены следующие 21 новые комбинации: N. baethei (Girault, 1922), comb.n., N. dei (Girault, 1922), comb.n., N. gigantea (Girault, 1915), comb.n., N. maxima (Girault, 1915), comb.n., N. odacon (Walker, 1838), comb.n., N. punctaticeps (Girault, 1928), comb.n. (перенесён из рода Anagyrodes); N. angulimaculata (Xu \& He, 2003), comb.n., N. bicoloripes (Hayat, 2003), comb.n., N. dilatata (Girault, 1932), comb.n., N. gigantica (Subba Rao, 1973), comb.n., N. longimarginalis (Subba Rao, 1973), comb.n., N. madhukari (Mani \& Kaul, 1973), comb.n., N. myersi (Waterston, 1928), comb.n., N. orientalis (Subba Rao, 1971), comb.n., N. poeta (Girault, 1928), comb.n., N. waterstoni (Subba Rao, 1971), comb.n., N. zora (Hayat, 2003), comb.n. (все из рода Carabunia); N. calicutana (Hayat, 2003), comb.n., $N$. giorgionei (Girault, 1932), comb.n., N. globosa (Girault, 1920), comb.n., N. uttara (Hayat, 2003), comb.n. (все из рода Paracladella). Вид Neocladia perkinsi Subba Rao, 1971, stat.rev., восстановлен в роде Neocladia (из рода Anagyrodes). Обозначен лектотип для $N$. punctaticeps. Собрана информация об известных хозяевах рода $\mathrm{Neo-}$ cladia. 


\section{Introduction}

The encyrtid (Hymenoptera: Encyrtidae) genus Neocladia Perkins, 1906 currently contains ten described species, some of which are known as internal, nymphal parasitoids of Cicadellidae [Noyes, 2010]. The genus is recognizable mainly by the extraordinarily expanded and flattened metatibia, a sickle-shaped mandible, and a 3 -segmented clava of the female antenna [Noyes \& Hayat, 1984].

The similar encyrtid genus Anagyrodes Girault, 1915 initially included three species from Australia [Girault, 1915; 1922] and one species from the Philippines [Girault, 1928b]. Noyes \& Hayat [1984] added four Australian taxa to the list of its species; the type specimen of one of them, A. odacon (Walker, 1838), had been collected by Charles Darwin in Hobart, Tasmania [Walker, 1838]. The most recent diagnosis of Anagyrodes was given by Dahms \& Gordh [1997]. Here we synonymize Anagyrodes as well as the genera Paracladella Girault, 1920 and Carabunia Waterston, 1928 under Neocladia. Earlier, Noyes \& Hayat [1984] treated the genera Elijahia Girault, 1928 and Schillerana Girault, 1932 (both from Australia) as synonyms of Carabunia, so they also become junior synonyms of Neocladia. Our expanded diagnosis of Neocladia in the broad sense reflects inclusion of the new synonyms suggested here.

Thus, 34 species of Neocladia are now being recognized as valid in the world fauna, including the two new species described herein. Of these, 22 described species belonged to the former genera Anagyrodes, Carabunia and Paracladella; a key for separation of most of them is provided (the key also includes the two newly described taxa). Host associations are known only for the four described and one undescribed species of these former genera: their hosts belong to three families (Aphrophoridae, Cercopidae (records need confirmation), and Clastopteridae) of Cercopoidea (Auchenorrhyncha: Cicadomorpha), feeding on such important crops and plants as sugarcane, coffee, cacao, Casuarina sp., and Hibiscus sp.; also, one undetermined species was reared in India from nymphs of the leafhopper Batracomorphus indicus (Lethierry, 1892) (Auchenorrhyncha: Cicadomorpha: Membracoidea: Cicadellidae: Iassinae) nymphs [Noyes \& Hayat 1984]. The ten species that were listed in Neocladia (s. str.) by Noyes [2010] remain to be thoroughly revised but that is beyond the scope of this communication. Their host associations are also poorly known: $N$. howardi Perkins, 1906 was found in association with a "common jassid" in Queensland, Australia [Perkins, 1906], which likely could be the large green jassid, Batracomorphus angustatus (Osborn, 1934) or a congeneric species; N. tibialis Annecke, 1965 was recorded as an internal, solitary, nymphal parasitoid of Batracomorphus capeneri Linnavuori, 1957 [a synonym of Batracomorphus punctatissimus (Melichar, 1908)] in South Africa [Annecke, 1965]; while $N$. indica (Agarwal, 1970) was most likely errone- ously reported from a Pseudococcus sp. (Sternorrhyncha: Pseudococcidae).

Trjapitzin [1973] founded the tribe Neocladiini Trjapitzin, 1973 and included the genera Neocladia and Carabunia into it. Trjapitzin \& Gordh [1978] placed Neocladia, together with the genera Carabunia and Prionomastix Mayr, 1876, in the tribe Prionomasticini Hoffer, 1955, subtribe Prionomasticina Hoffer, 1955 of the subfamily Encyrtinae, but without a justification or comments. Gordh \& Trjapitzin [1981] synonymized Neocladiini under Prionomasticini. Dahms \& Gordh [1997] included Anagyrodes and Neocladia in Prionomasticini, but later Hayat [2006] placed them in the tribe Encyrtini Walker, 1837 of the same subfamily. We do not agree with the latter placement because species of the genera Encyrtus Latreille, 1809 and Aethognathus Silvestri, 1915 are parasitoids of Coccidae (Sternorrhyncha: Coccoidea), whereas it is likely that members of the genera Eugahania Mercet, 1926, Neocladia, and Prionomastix represent another evolutionary lineage of encyrtids that specialize in parasitizing various Cercopoidea and Membracoidea (Auchenorrhyncha: $\mathrm{Ci}$ cadomorpha). Sharkov [1984] stated, based on the shape of the mandibles and the forewing venation, that Neocladia is related only to Eugahania, excluded these two genera from the Prionomasticini, and reestablished the tribe Eugahaniini Trjapitzin, 1973; this point of view was followed by Trjapitzin [1989]. Noyes \& Hayat [1984] stated that the tribe Neocladiini was possibly too narrowly defined by Trjapitzin [1973] and supposed that Anagyrodes is probably closest to Eugahania (the latter is easily distinguishable from Neocladia s. 1. by the costal cell of the forewing being strongly excised at apex). In the absence of a key to the tribes, supporting molecular data, and a rigorous phylogenetic analysis of the genera on a global basis, tribal arrangement within the Encyrtidae remains to be defined based on the limited morphological characters and data on host associations, but also largely on the knowledge and intuition of the few experienced taxonomists working on this diverse and economically important group. The personal opinion of the first author of this communication is that Neocladia belongs to Eugahaniini.

Acronyms of the depositories of the specimens are as follows:

BMNH - The Natural History Museum, London, England, UK;

HNHM - Hungarian National History Museum, Budapest, Hungary;

QMBA - Queensland Museum, South Brisbane, Queensland, Australia;

UCRC — Entomology Research Museum, University of California, Riverside, California, USA;

ZIN - Zoological Institute, Russian Academy of Sciences, St. Petersburg, Russia.

An abbreviation used in the text is:

$\mathrm{F}$ - an antennal funicular segment. 


\section{Genus Neocladia Perkins, 1906}

Neocladia Perkins, 1906: 251. Type species: Neocladia howardi Perkins, 1906, by monotypy.

Anagyrodes Girault, 1915: 155. Type species: Anagyrodes maximus Girault, 1915, by original designation. syn.n.

Paracladella Girault, 1920: 142. Type species: Paracladella globosa Girault, 1920, by monotypy. syn.n.

Carabunia Waterston, 1928: 249. Type species: Carabunia myersi Waterston, by original designation. syn.n.

Elijahia Girault, 1928a: 1. Type species: Elijahia poeta Girault, 1928, by monotypy. Synonymy under Carabunia by Noyes \& Hayat, 1984: 244. syn.n.

Schillerana Girault, 1932: 6. Type species: Schillerana dilatata Girault, 1932, by monotypy. Synonymy under Carabunia by Noyes \& Hayat, 1984: 244. syn.n.

Other synonyms of Neocladia were listed by Dahms \& Gordh [1997] and Noyes [2010].

DIAGNOSIS. Female. Body usually large, not flattened, dark-colored, with metallic luster. Head hypognathous, more or less menisciform, its anterior profile broadly rounded and posterior margins acute. Occipital margin sharp. Eyes almost touching occiput. Frontovertex broad. Ocellar triangle obtuse. Facial area with short scrobes (moderately deep and either confluent or not confluent above). Interantennal prominence narrowly convex. Toruli rather high on face. Antennal scape almost linear, only slightly widened at apex; pedicel short, unmodified; funicle 6-segmented, not broadened; clava either 3-segmented or entire. Malar space long. Subocular suture absent. Labrum well-developed. Mandible with 1 sickle-shaped tooth (Figs 3, 16), or also with 1-3 subsidiary small teeth. Maxillary palpus 4-segmented (Fig. 17), with apical segment usually very long; labial palpus 2- or 3-segmented. Pronotum transverse. Mesoscutum wider than long; notauli absent. Axillar median angles more or less broadly joining. Wings long, forewing usually more or less infuscate. Submarginal vein of forewing without triangular expansion in its apical third; marginal vein absent, punctiform, or longer than wide; stigmal vein curved, either weakly broadened or not broadened at apex, usually without uncus; postmarginal vein not longer than stigmal vein in the New World species, but very long in the Old World species. Linea calva with or without filum spinosum. Metatibia from quite moderately (Fig. 13) or more or less strongly (Figs 6, 7, 11) broadened to very strongly (Fig. 18) or sometimes extraordinarily broadened and flattened, particularly in females of Neocladia s. str.; metabasitarsus usually compressed. Ovipositor sheaths not exserted or only slightly exserted.

Male. Generally similar to female except for the normal sexually dimorphic features such as the antenna and genitalia. Males of Neocladia are insufficiently studied and, in fact, are hardly known for the species in the former genus Anagyrodes; the male of $N$. myersi (Waterston, 1928), comb.n. has the antennal funicle without branches (Fig. 12), but the male of an unidentified species from India, reared from nymphs of Batracomorphus indicus (identified by J.S. Noyes as Anagyrodes sp., examined material in BMNH, whose female has a moderately broadened metatibia) as well as the males of $N$. howardi and $N$. tibialis have the antennal funicle with branches.

COMMENTS. In the species of Neocladia s. str. the clava of the female antenna is 3-segmented, and in the species of the former genus Anagyrodes it is also 3-segmented (but the septa may be incomplete), whereas in the species belonging to the former genera Carabunia and Paracladella the clava of the female antenna is entire. We consider this and other differences as being non-substantial to separate Anagyrodes, Carabunia and Paracladella from Neocladia, especially because they share the common, very distinct feature (a sickle-shaped man- dibular tooth) that corroborates the synonymies suggested here. The very strongly (or sometimes extraordinarily) expanded and flattened metatibia (particularly in females) of Neocladia $\mathrm{s}$. str. is in our opinion just an extreme state of the same character (the metatibia more or less strongly broadened) that is found in the former genera Anagyrodes, Carabunia, and Paracladella. Also we consider variations of punctation on the frontovertex and presence or absence of branches on the funicle of the male antenna in these nominal genera not to be of generic value. Moreover, some species of both Neocladia (s. str.) and Anagyrodes are known as parasitoids of nymphs of Cicadellidae [Noyes \& Hayat, 1984].

At this point of the still poor knowledge of Neocladia, we are reluctant to subdivide the genus even to informal species groups. Particularly, the differences between the species of Neocladia s. str. and the ones of the former genus Anagyrodes (all of them have a 3-segmented clava of the female antenna) are not clearcut (although reliable data are available only for some of the taxa): in the former, the female metatibia is about $2.0-2.9 \mathrm{x}$ as long as wide whereas in the latter, the female metatibia is about $3.0-5.3 \mathrm{x}$ as long as wide.

PARTIAL KeY TO SPECIES OF NEOCLADIA (FEMALES)

(excludes $N$. angulimaculata (Xu \& He, 2003), comb.n., N. odacon (Walker, 1938), comb.n., and also ten species of Neocladia s. str. listed by Noyes [2010])

1(14) Antennal clava 3-segmented, sometimes septa incomplete.

2(5) Mesoscutum densely setose.

3(4) Length about $3.0 \mathrm{~mm}$ 7. N. gigantea

4(3) Length about $1.8 \mathrm{~mm}$.................. 21. N. punctaticeps

5(2) Mesoscutum not densely setose.

6(11) Antennal funicle segments quadrate or transverse, only F1 may be somewhat longer than wide.

7(8) Forewing slightly, more or less uniformly infuscate, without distinct darker band(s) (Fig. 2) ... 2. N. baethei

$8(7)$ Forewing with distinct darker band(s).

9(10) F1 as long as wide; septa dividing segments of antennal clava complete. Infumation on forewing disc under stigmal vein broad, almost extending to posterior margin of wing ............................................ 19. N. perkinsi

10(9) F1 a little longer than wide (Fig. 4); septa dividing segments of antennal clava incomplete. Infumation on forewing disc under stigmal vein small (Fig. 5) .......... 5. N. dei

11(6) All antennal funicle segments longer than wide.

12(13) Antenna (except brown clava), lateral and posterior parts of scutellum, legs, and gaster (except black posterior part) yellow. Forewing faintly infuscate; marginal vein punctiform. Propodeum polished with very weak fine reticulations. $2.6 \mathrm{~mm}$........................... 14. N. maxima

13(12) Antenna black (except yellowish-brown scape with obsure dorsal margin); scutellum entirely violet-bronze-green; legs brownish-yellow, with black meso- and metacoxae, apex of mesotibial spur and metatibia; entire gaster greenviolet-blue. Forewing infuscate, with broad transverse hyaline stripe beyond stigmal vein; marginal vein $3 \mathrm{x}$ as long as wide. Central elevated part of propodeum with cellulate sculpture. $3.8 \mathrm{~mm}$ (Fig. 11) 15. N. mikhailovi

14(1) Antennal clava entire.

15(20) All antennal funicle segments distinctly longer than wide.

16(17) Marginal vein of forewing punctiform. Metatibia rounded apically. $4.2 \mathrm{~mm}$................... 8. $\mathrm{N}$. gigantica

17(16) Marginal vein of forewing approximately $3 x$ as long as wide. Metatibia angulate at apex.

18(19) Distance from each posterior ocellus to eye margin 2 


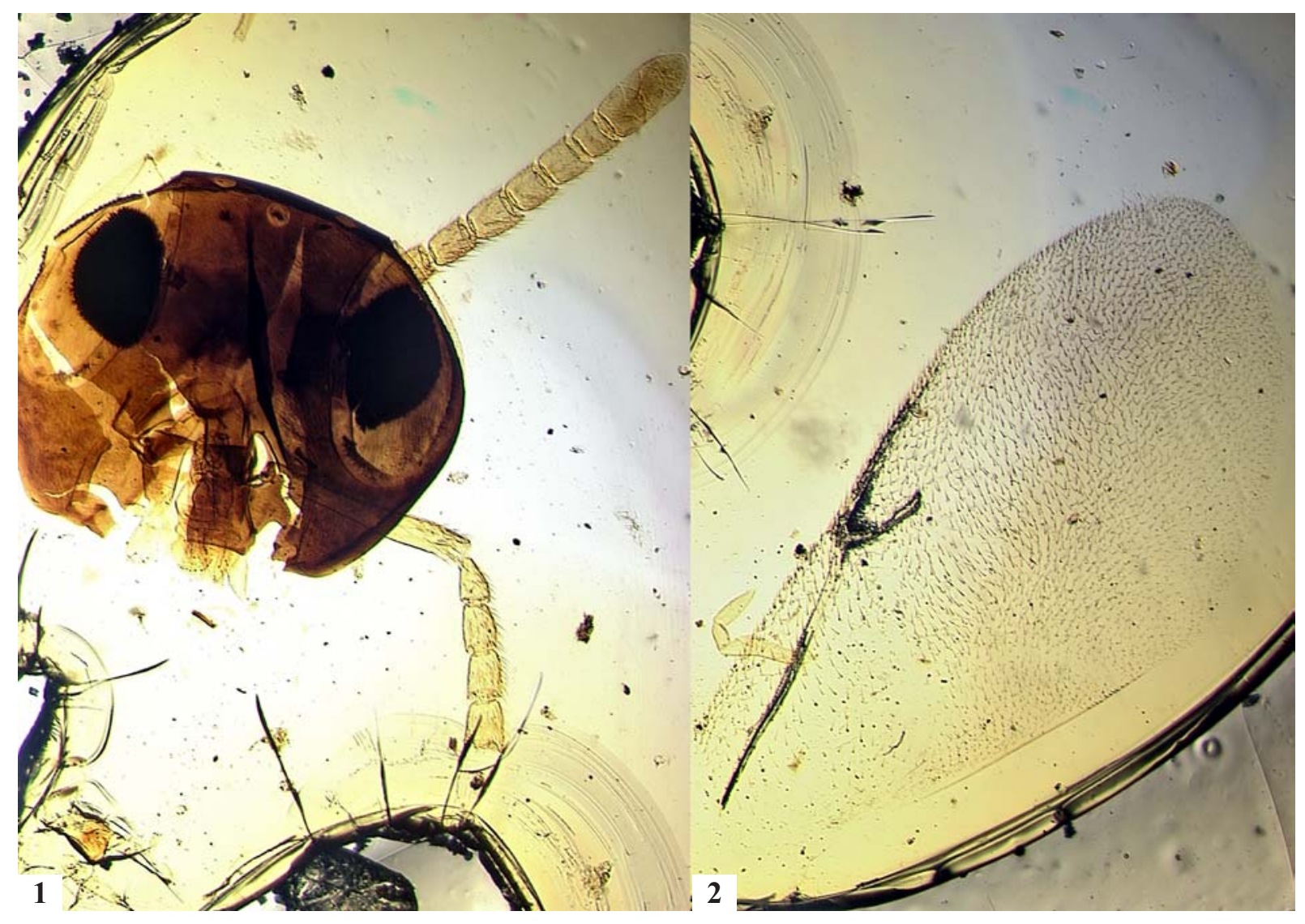

Figs 1-2. Neocladia baethei, female (paralectotype): 1 - head (with one of the antennae incomplete) and mandible (detached, upper left corner); 2 - forewing.

Рис. 1-2. Neocladia baethei, самка (паралектотип): 1 — голова (одна из антенн неполная) и мандибула (изображена отдельно); 2 - переднее крыло.

ocellar diameters. $3.7 \mathrm{~mm}$....... 12. $N$. longimarginalis 19(18) Distance from each posterior ocellus to eye margin 1 ocellar diameter. 13. N. madhukari 20(15) Not all antennal funicle segments longer than wide.

21(24) Postmarginal vein of forewing not longer than stigmal vein; forewing with 2 infuscations: at the level of stigmal vein and at apex.

22(23) Marginal vein of forewing absent; postmarginal vein somewhat shorter than stigmal vein (4:5). Metatibia not strongly broadened, more than $4 \mathrm{x}$ as long as wide, with apex transverse, straight and angular; metabasitarsus $3-$ $4 \mathrm{x}$ as long as wide 16. N. myersi

23(22) Marginal vein of forewing punctiform; postmarginal vein $2 \mathrm{x}$ shorter than stigmal vein. Metatibia strongly broadened, with convex margins, about $3.5 \mathrm{x}$ as long as wide, with apex rounded; metabasitarsus $2 \mathrm{x}$ as long as wide 23. N. waterstoni

24(21) Postmarginal vein of forewing longer than stigmal vein. 25(26) Tegula white

26(25) Tegula dark.

27(28) First gastral (III metasomal) tergite testaceous-yellow, other gastral tergites contrastingly dark brown. Marginal vein of forewing a little longer than wide; forewing infuscate only at apex

24. N. zora

28(27) Entire gaster completely dark brown to black, metallic.

29(30) Antennal scape not more than $3 \mathrm{x}$ as long as wide. Marginal vein of forewing absent; forewing infuscate only behind stigmal vein
30(29) Antennal scape 3-6x as long as wide.

31(36) Marginal vein of forewing absent, punctiform or almost punctiform.

32(33) Antennal clava as long as combined length of 3 preceding funicle segments. Marginal vein of forewing almost punctiform. Metatibia strongly broadened, somewhat more than $2 \mathrm{x}$ as long as wide 22. N. uttara

33(32) Antennal clava as long as combined length of 2 preceding funicle segments.

34(35) Marginal vein of forewing absent; forewing infuscate beneath stigmal vein as a rather broad transverse stripe 9. N. giorgionei

35(34) Marginal vein of forewing punctiform; forewing infuscate only in its apical third ........... 18. N. orientalis

36(31) Marginal vein of forewing distinctly longer than wide.

37(40) Apex of forewing strongly infuscate.

38(39) F1 brownish-yellow. Forewing with broad median infuscate transverse stripe. First gastral (III metasomal) tergite yellow, other gastral tergites contrastingly dark brown ............................................ 3. N. bicoloripes

39(38) F1 black. Forewing (Figs 9-10) without infuscate median stripe. Gaster entirely dark with metallic luster. 4 $\mathrm{mm}$................................................ 11. N. korotjaevi

40(37) Apex of forewing not infuscate.

41(42) Forewing with median transverse dark stripe

$$
\text { 4. N. calicutana }
$$

42(41)Forewing without median transverse dark stripe, weakly infuscate

6. N. dilatata 


\section{Alphabetical synopsis of species}

\section{Neocladia angulimaculata (Xu \& He, 2003), comb.n.}

(Not included in the key)

Xu \& He, 2003: 523-524, 539-540 (Carabunia).

China (Fujian). Biology unknown.

We are unable to include this species in the key based solely on its original description, without examination of the type material.

\section{Neocladia baethei (Girault, 1922), comb.n.}

Figs 1-2.

Girault, 1922: 103 (Anagyrodes); Noyes \& Hayat, 1984: 229 (Anagyrodes); Dahms \& Gordh, 1997: 45 (Anagyrodes).

Australia (Queensland). Biology unknown.

We examined the lectotype and one paralectotype females of Anagyrodes baethei in QMBA (designated by Dahms $\&$ Gordh [1997]). Length of the lectotype $2.2 \mathrm{~mm}$. Illustrated here, to facilitate recognition of this species, are the head, antenna and mandible (Fig. 1), and also the forewing (Fig. 2) of the paralectotype.

3. Neocladia bicoloripes (Hayat, 2003), comb.n.

Hayat, 2003: 206-207 (Carabunia); Hayat, 2006: 52-53 (Carabunia).

India (Kerala). Biology unknown.

\section{Neocladia calicutana (Hayat, 2003), comb.n.}

Hayat, 2003: 229 (Paracladella); Hayat, 2006: 54 (Paracladella). India (Kerala). Biology unknown.

\section{Neocladia dei (Girault, 1922), comb.n.} Figs 3-5.

Girault, 1922: 100 (Paracladella); Noyes \& Hayat, 1984: 229 (Anagyrodes); Dahms \& Gordh, 1997: 45-46 (Anagyrodes).

Australia (Queensland, South Australia). Biology unknown.

Length of female about $2.2 \mathrm{~mm}$. Dahms \& Gordh [1997] indicated 2 female and 1 male specimens from Cooloola, Queensland, Australia, among the material of this species in QMBA but we found that all of these are females. Illustrated here, to facilitate recognition of this species, are the mandibles (Fig. 3), antenna ( Fig. 4), and forewing (Fig. 5) of the female.

\section{Neocladia dilatata (Girault, 1932), comb.n.}

Girault, 1932: 6 (Schillerana); Noyes \& Hayat, 1984: 244 (Carabunia); Dahms \& Gordh, 1997: 94 (Carabunia).

Australia (Queensland). Biology unknown.

7. Neocladia gigantea (Girault, 1915), comb.n.

Girault, 1915: 156 (Anagyrodes giganteus); Noyes \& Hayat, 1984: 229 (Anagyrodes giganteus); Dahms \& Gordh, 1997: 46-47 (Anagyrodes giganteus).

Australia (Queensland). Biology unknown.
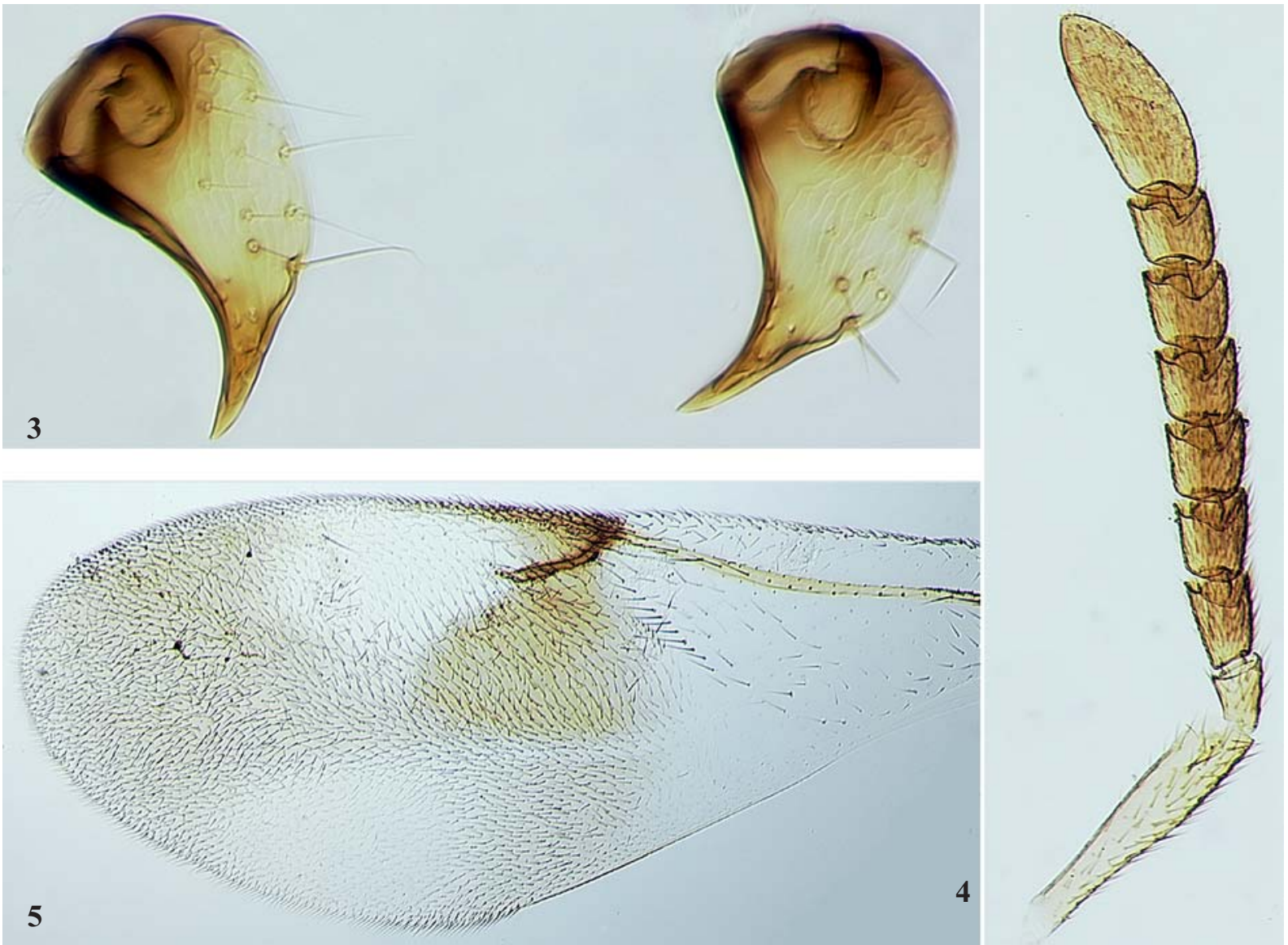

Figs 3-5. Neocladia dei, females (Cooloola, Queensland, Australia): 3 - mandibles; 4 - antenna; 5 - forewing.

Рис. 3-5. Neocladia dei, самка (Cooloola, Queensland, Australia): 3 - мандибулы; 4 - антенна; 5 - переднее крыло. 
8. Neocladia gigantica (Subba Rao, 1973), comb.n.

Subba Rao, 1973: 485-486 (Carabunia).

Uganda. Host: Ptyelus flavescens (Fabricius, 1794) (Aphrophoridae).

\section{Neocladia giorgionei (Girault, 1932), comb.n.}

Girault, 1932: 4 (Paracladella); Noyes \& Hayat, 1984: 315 (Paracladella); Dahms \& Gordh, 1997: 257-258 (Paracladella).

Australia (Queensland). Biology unknown.

10. Neocladia globosa (Girault, 1920), comb.n.

Girault, 1920: 142 (Paracladella); Noyes \& Hayat, 1984: 315 (Paracladella); Dahms \& Gordh, 1997: 256-257 (Paracladella).

Australia (Queensland). Biology unknown.

\section{Neocladia korotjaevi \\ V. Trjapitzin \& S. Triapitsyn, sp.n.}

Figs 6-10.

TYPE MATERIAL. Holotype $P$ (ZIN) on point, with one antenna and a pair of wings mounted separately on a slide. Original labels: 1. "VIETNAM, Ba Thuoc, 125 km NW Thanh Hoa, 30.01.1989, B. Korotjaev"; 2. "Carabunia sp. det. A.V. Sharkov".

DESCRIPTION. Female (holotype, Figs 6-7). Head menisciform, a little wider than high (10:9), and much shorter than long (4:9). Occipital margin slightly concave, sharp; posterior margins of head with mouth orifice also sharp. Posterior margins of eyes almost touching occipital margin. Width of vertex somewhat less than $0.5 x$ maximum head width (11:25); frontovertex (measured medially) a little longer than width of vertex (25:22). Apical angle of ocellar triangle somewhat more than $90^{\circ}$; distance between posterior ocelli more than distance from posterior to anteri- or ocellus (5:3); distance from posterior ocelli to eye margins approximately equal to 2 diameters of an ocellus, and distance to occipital margin somewhat more than that. Anterior margin of frons (seen from above) slightly concave. Facial depression large, almost extending to mouth margin, with evenly rounded upper border of scrobes short, joining above. Toruli close to each other, separated by narrow median prominence, only slightly overpassing below level of lower margins of toruli; distance between toruli less than distance from them to eye margins $(2: 3)$, and $3 x$ less than that to mouth margin. Mouth orifice about $0.33 \mathrm{x}$ maximum head width; mouth margin concave. Malar space height less than that of eye (10:17). Subocular suture absent. Palpi thin. Antenna (Fig. 8) with scape long, approximately $5.3 \mathrm{x}$ as long as wide at apex; its dorsal margin slightly concave in dorsal half; pedicel $3 \mathrm{x}$ shorter than scape and $2 \mathrm{x}$ as long as wide at apex; F1 long, almost $2 x$ longer than pedicel (15:8) and $3 \mathrm{x}$ as long as wide at apex; F2 $1.7 \mathrm{x}$ as long as wide at apex and shorter than F1 (2:3); F3 a little longer than wide (8:7) and shorter than F2 (4:5); F4 and F5 similar to F3; F6 slightly wider than long (5:4); clava entire, $2.6 \mathrm{x}$ as long as wide and equal in length to the combined length of F5 and F6. Pronotum $5 \mathrm{x}$ as wide as long, with concave posterior margin, and $4 \mathrm{x}$ shorter than mesoscutum, the latter moderately convex and wider than long (5:4). Axilla rather large and somewhat convex. Scutellum a little shorter than mesoscutum and slightly longer than wide basally, with very thin longitudinal keel in basal part, lateral borders of scutellum slightly convex, and its apex rounded, overhanging propodeum, concealing completely its median part. Sides of propodeum almost straight (in dorsal view) and shorter than scutellum (12:17); posterolateral corners of propodeum as

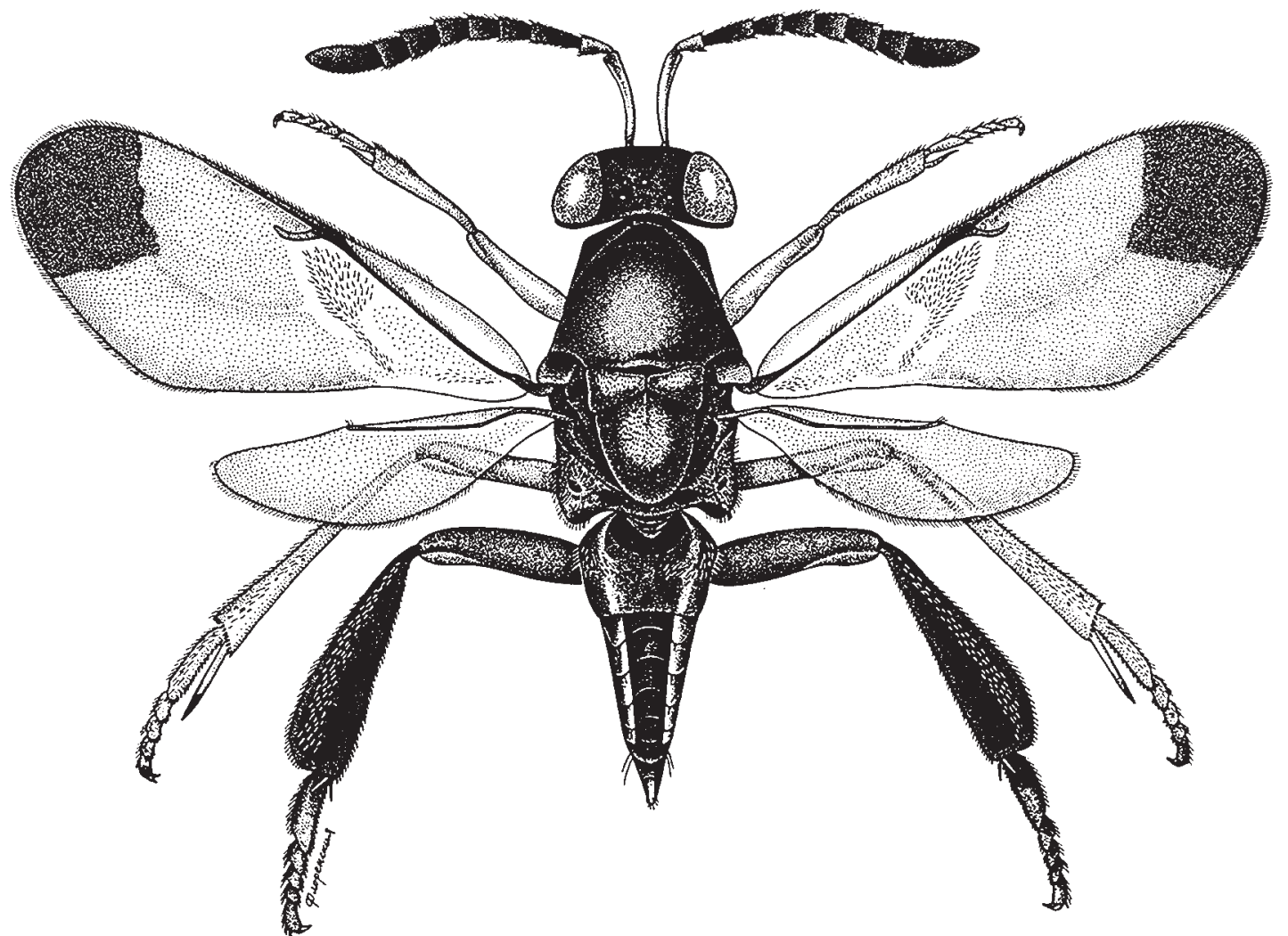

Fig. 6. Neocladia korotjaevi sp.n., female (holotype), dorsal view (drawing by N.A. Florenskaya).

Рис. 6. Neocladia korotjaevi sp.n., самка (голотип), сверху (рисунок Н.А. Флоренской). 

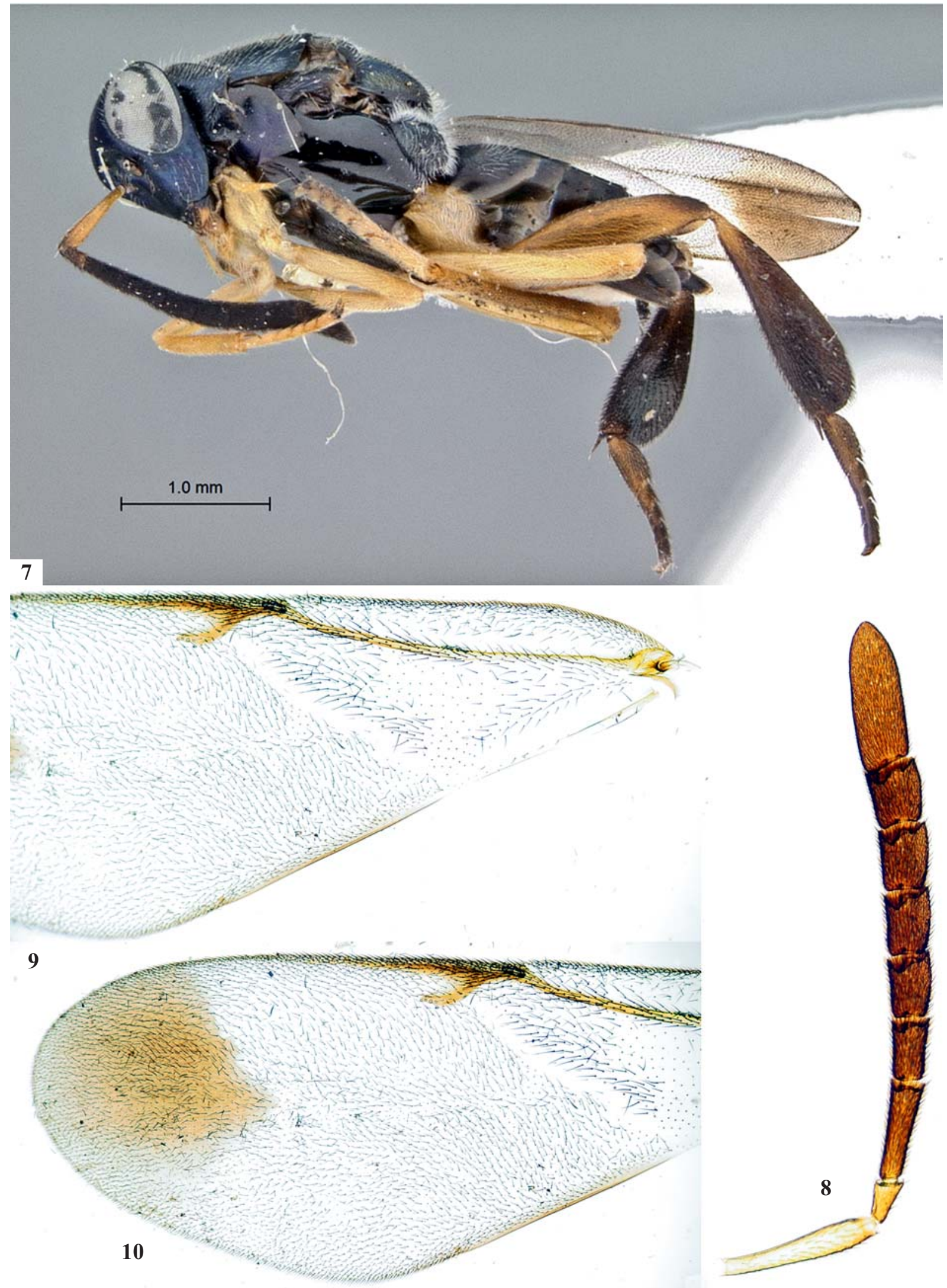

Figs 7-10. Neocladia korotjaevi sp.n., female (holotype): 7 - habitus, lateral view; 8 - antenna; 9 - base of forewing; 10 - apex of forewing.

Рис. 7-10. Neocladia korotjaevi sp.n., самка (голотип): 7 - габитус, сбоку; 8 - антенна; 9 - основание переднего крыла; 10 вершина переднего крыла. 
acute dents. Forewing (Figs 9-10) long, well extending beyond apex of gaster, $2.7 \mathrm{x}$ as long as wide; stigmal vein somewhat longer than marginal vein (4:3); postmarginal vein very long. Hind wing $2.9 \mathrm{x}$ as long as wide, with disc hyaline, mostly densely setose (except basally). Mesotibial spur shorter than mesobasitarsus (18:23). Metatibia 3.6x as long as wide at apex, the latter transversely truncate. Mesobasitarsus $2.4-2.5 \mathrm{x}$ as long as wide. Gaster as long as mesosoma. Position of pygostyles not possible to ascertain. Hypopygium extending to apex of gaster. Ovipositor sheaths thick, slightly exserted.

Body dark, with metallic luster. Vertex gold-bronzegreen-violet-blue. Frons, face, and malar space blue. Labrum dark. Palpi yellow. Antennal radicle dark, scape brownishyellow, pedicel, funicle and clava black. Mesoscutum, axilla and tegula with strong green-blue luster; scutellum with rather dull blue-green luster. Mesopleura black, with bluish and greenish reflections. Forewing infuscate only in its apical third, the infuscation with triangular protuberance directed basad; submarginal and stigmal veins brownish, marginal and postmarginal veins dark. Legs brown-yellow with the following parts dark: apex of last segment of foretarsus, mesocoxa, mesotarsus (except basal segment), apices of metafemur, metatibia (except bases), and metatarsus. Gaster with bronze-violet luster. Exserted part of ovipositor sheath black.

Frons with fine transverse reticulate sculpture formed by narrow meshes; vertex minutely reticulate-cellulate with rather dense scattered coarse punctation. Mesoscutum with minute reticulation and densely punctulate; scutellum with larger meshes of sculpture and with somewhat bigger points than mesoscutum. Mesopleura smooth, strongly brilliant. Lateral parts of propodeum with coarse sculpture.

Mesoscutum and scutellum covered with dense clear hairs, especially long and dense on lateral border and apex of scutellum. Hyaline parts of forewing with dark pubescence, the hairs longer before linea calva, the latter narrow and closed posteriorly; filum spinosum absent. Sides and posterior margins of lateral parts of propodeum with dense and rather long clear pubescence. Length $4 \mathrm{~mm}$.

Male unknown.

ETYMOLOGY. This species is named after its collector, Dr. Boris Alexandrovich Korotjaev, specialist on the systematics of Curculionidae (ZIN).

HOSTS. Unknown.

\section{Neocladia longimarginalis (Subba Rao, 1973), comb.n.}

Subba Rao, 1973: 485-487 (Carabunia).

China [Zhang \& Huang, 2004], and Malaysia, from nymphs of unidentified Cercopidae on sugarcane, Saccharum officinarum.

\section{Neocladia madhukari (Mani \& Kaul, 1973), comb.n.}

Mani \& Kaul in: Mani et al., 1973: $72-74$ (Coelopencyrtus); Mani, 1989: 990-991 (Carabunia); Hayat, 2006: 52-53 (Carabunia).

India (Himachal Pradesh). Biology unknown.

\section{Neocladia maxima (Girault, 1915), comb.n.}

Girault, 1915: 155-156 (Anagyrodes maximus); Noyes \& Hayat, 1984: 228-229 (Anagyrodes maximus); Dahms \& Gordh, 1997: 44 45 (Anagyrodes maximus).

Australia (Queensland). Biology unknown.

\section{Neocladia mikhailovi \\ V. Trjapitzin \& S. Triapitsyn, sp.n. Fig. 11.}

TYPE MATERIAL. Holotype + (HNHM) on card; F3-F6 and clava of the right antenna, and also tibia and tarsus of the right hind leg are missing (Fig. 11). Original labels: 1. "N. E. BURMA, Kambaiti, 2000 m, 12/5.1934, Malaise"; 2. "O"; 3. "coll. Dr. J. Erdös"; 4. [in pencil, apparently J. Erdös' manuscript name] "Prionomastix burmana".

DESCRIPTION. Female (holotype, Fig. 11). Eyes reaching occipital margin, the latter slightly concave, acute. Width of vertex somewhat less than half maximum head width (5:12); frontovertex a little wider than long (7:6). Ocelli forming an obtuse triangle, with apical angle about $120^{\circ}$, distance between posterior ocelli $2 \mathrm{x}$ more than distance from posterior to anterior ocellus; distance from posterior ocelli to eye margins more than that to occipital margin (4:3). Antennal scape approximately $5 \mathrm{x}$ as long as wide; pedicel $3 \mathrm{x}$ shorter than scape and $2 \mathrm{x}$ longer than wide at apex; all funicle segments longer than wide; F1 longer than wide, about $3 \mathrm{x}$ as long as wide at apex and $2 \mathrm{x}$ longer than pedicel; F2 more than $2 \mathrm{x}$ as long as wide $(5: 2)$ and shorter than F1 (3:5); F3 similar to F2; F4 as long as the F3 but a little wider (6:5); F5 as wide as F4 but slightly longer; F6 more or less similar to F5; clava 3-segmented, about $3 \mathrm{x}$ as long as wide, a little longer than combined length of F5 and F6 and slightly wider than F6 (7:6); septa dividing claval segments straight and almost transverse; first claval segment about half length of clava, third claval segment small; apex of clava acutely rounded. Pronotum short, with posterior margin concave. Mesoscutum moderately convex, wider than long (25:17). Axilla convex. Scutellum a little shorter than mesoscutum and slightly longer than wide; apex of scutellum with fine bordering, separated by a ditch. Wings not abbreviated; forewing $2.7 \mathrm{x}$ as long as wide; submarginal vein thin, weakly curved; marginal vein slightly broadening towards apex, $3 \mathrm{x}$ longer than its maximum width; stigmal vein $1.5 \mathrm{x}$ as long as marginal vein, curved, broadening towards apex, the latter rounded, without uncus; postmarginal vein very long, but its apex is difficult to ascertain. Hind wing very broad: approximately $3 \mathrm{x}$ as long as wide and its maximum width as 17:27 to maximum width of forewing. Mesopleura distinctly not reaching base of gaster, separated from the latter by lateral parts of propodeum. Metapleura as narrow sclerites. Propodeum with 5 areas separated by deep longitudinal furrows: the middle area convex, strongly protruding posteriorly; two areas lateral to the middle area short, transverse; lateral areas of propodeum strongly developed, posteriorly at right angles, considerably convex at sides, with spiracles in their anterior parts. Mesobasitarsus very long, only a little shorter than all following tarsal segments together (4:5), $4 \mathrm{x}$ as long as wide at apex. Gaster shorter than mesosoma (3:4), 1.5x as long as wide, conically narrowing towards apex. Metasomal tergites III-VI (gastral tergites 1-4) and small IX syntergite discernable from above; posterior margins of tergites transverse; III tergite large, occupying 0.4 gaster length and wider than long (5:3); tergite IV more than $2 \mathrm{x}$ shorter than tergite III $(5: 12)$ and about $4 \mathrm{x}$ as wide as long; $\mathrm{V}$ tergite somewhat shorter than tergite IV and $6 \mathrm{x}$ as wide as long; tergite VI with evenly convex posterior margin, somewhat longer than tergite $\mathrm{V}$ (4:3) and approximately $4 \mathrm{x}$ wider than long. Pygostyles near apex of gaster: together with base of IX syntergite, possibly, hidden under overhanging apical part of tergite VI. Visible part of syntergite IX triangular, conically narrowing towards apex, the latter truncate with a smooth incision. Length of exserted part of ovipositor sheaths about 0.5 length of visible 


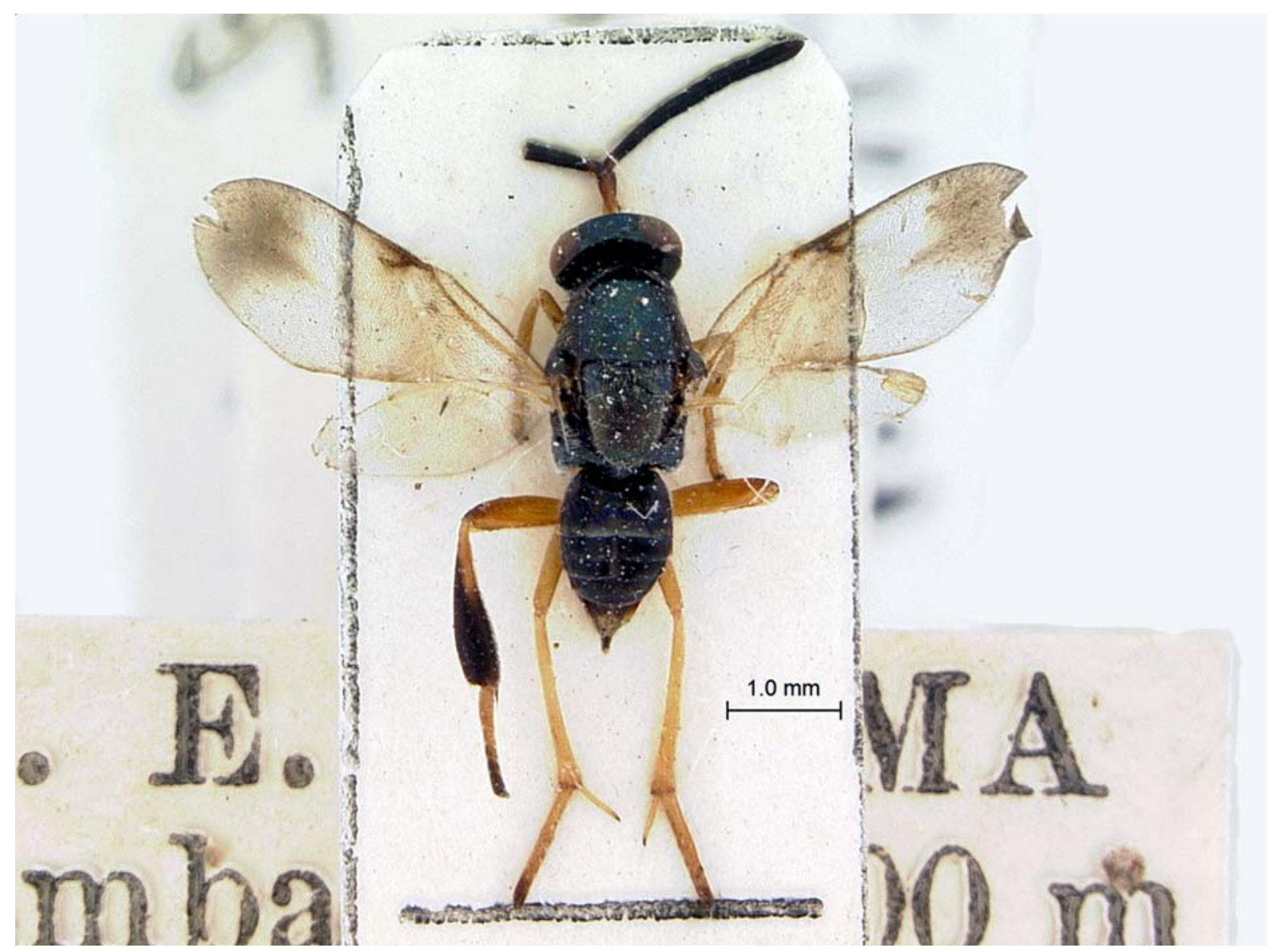

Fig. 11. Neocladia mikhailovi sp.n., female (holotype, dorsal view).

Рис. 11. Neocladia mikhailovi sp.n., самка (голотип, сверху).

part of syntergite IX, approximately $12 \mathrm{x}$ shorter than gaster and more than $2 x$ shorter than mesotibial spur (9:23).

Body dark, with strong metallic sheen. Frontovertex greenish-blue with bluish-green posterior occipital margin. Scape yellowish-brown, with obscure dorsal margin, other antennal segments black. Pronotum, mesoscutum, axilla and tegula green-blue; scutellum violet-bronze-green. Mesopleura black. Propodeum black, with weak green-blue luster. Forewing infuscate, with lighter base, costal cell and a broad transverse hyaline stripe beyond stigmal vein; apical infuscation of the wing with a median protuberance directed proximally. Legs brown-yellow, with meso- and metacoxae, apex of mesotibial spur, and metatibia (except base) black; apical segment of mesotarsus darkened. Gaster green-violet-blue. Exserted part of ovipositor sheath black.

Vertex with more or less rounded cellulate sculpture, particularly minute at occipital margin. Frons with large transversely cellulate sculpture. Vertex, in addition, with pits (big points) not in rows. Mesoscutum, axilla and scutellum minutely cellulate, with dense punctation. Central elevated part of propodeum with cellulate sculpture, but most areas of propodeum lateral to this elevation weakly sculptured; lateral parts of propodeum with minute sculpture.

Antennal flagellum with almost inconspicuous pubescence. Mesosoma dorsally with short clear hairs, lateral parts of propodeum with dense, long, clear pubescence. Costal cell and base of forewing (till linea calva) pubescent; linea calva without filum spinosum, closed posteriorly; other parts of forewing pubescent; marginal fringe very short. Length $3.8 \mathrm{~mm}$.
Male unknown.

ETYMOLOGY. This new taxon is named after Dr. Kirill Glebovich Mikhailov, publisher of the Russian Entomological Journal (Zoological Museum of the Moscow State University, Moscow, Russia).

HOSTS. Unknown.

\section{Neocladia myersi (Waterston, 1928), comb.n.} Figs 12-14.

Waterston, 1928: 249-251 (Carabunia); Myers, 1930: 341352 (Carabunia); Maple, 1947: 70 (Carabunia); García-Jiménez, 1982: 86-87 (Carabunia); Trjapitzin et al., 2004: 58 (Carabunia).

Cuba, from Clastoptera undulata Uhler, 1864 and Clastoptera sp. (Clastopteridae) [Waterston, 1928; Myers, 1930]; Haiti, from Clastoptera sp. [Myers, 1930]; Mexico (Tabasco), from Clastoptera globosa Fowler, 1897 on cacao [GarcíaJiménez, 1982].

MATERIAL EXAMINED. Bahamas, Grand Bahama Island, Freeport, Xanadu Beach, 16.x.1982, D.M. LaSalle, sand dunes (1 9 , UCRC). Mexico: Nuevo León, San Pedro Garza García, Fracción (Colonia) Carrizalejo, M.A. Rodríguez (1 o, UCRC); Yucatán, Pisté, F.D. Bennett, from Clastoptera sp. on Hibiscus rosa-sinensis ( 2 우, F.D. Bennett collection, Isle of Man, UK). Nicaragua, Managua, Managua, 6.ix.1975, from Clastoptera sp. on Hibiscus sp., F.D. Bennett ( 2 웅 $2 \mathrm{O}^{7} \mathrm{O}^{7}$, UCRC). USA, Florida, Pinellas Co., 20.ix.1967, C.O. Mohr, from C. undulata (1 $9,10^{7}$, UCRC).

Records of N. myersi from Puerto Rico (USA) and several other countries need to be verified based on examination of the voucher specimens, if such exist; some of them pertain to 

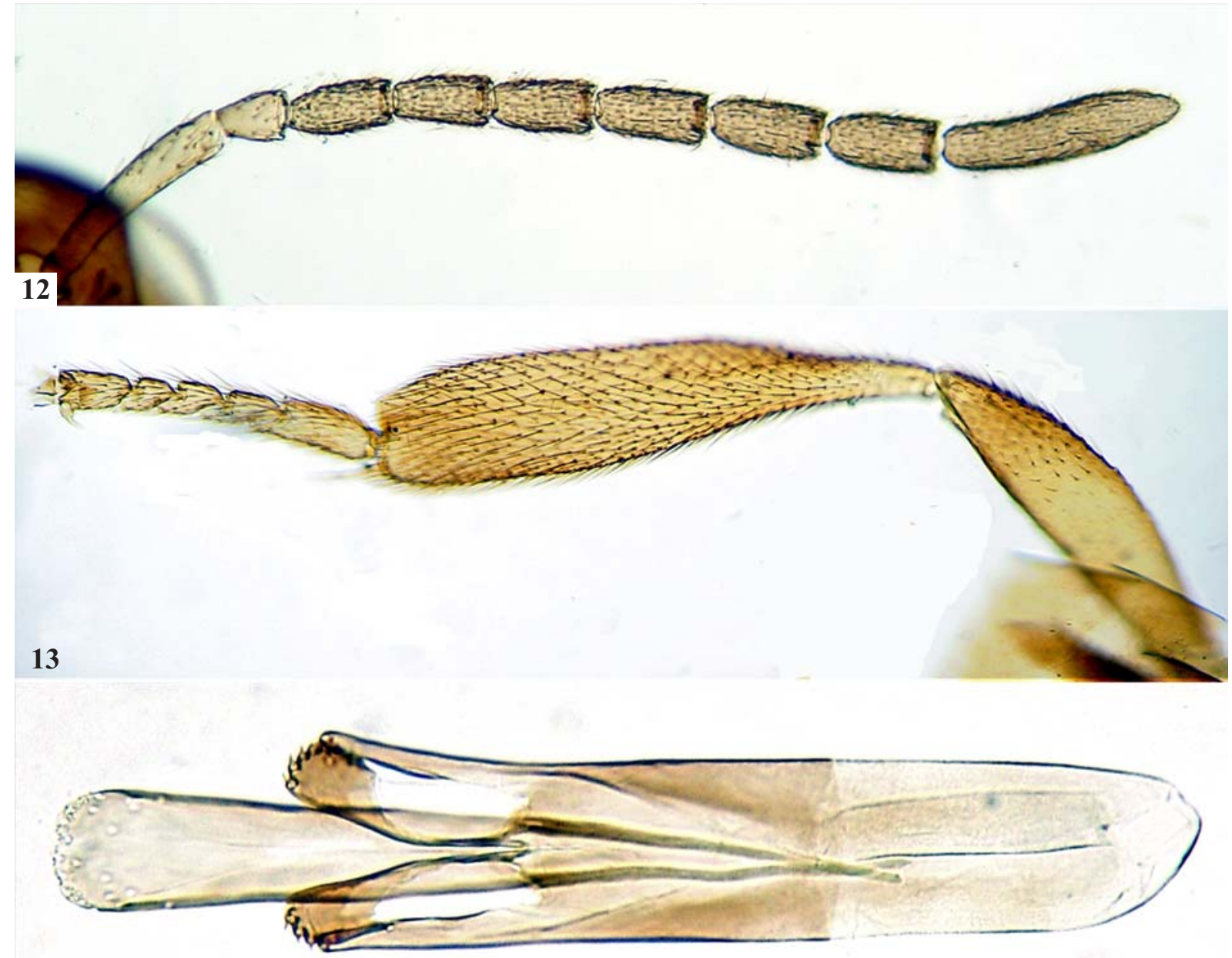

14

Figs 12-14. Neocladia myersi, male (Pinellas Co., Florida, USA): 12 - antenna; 13 - hind leg; 14 - genitalia.

Рис. 12-14. Neocladia myersi, самец (Pinellas Co., Florida, USA): 12 - антенна; 13 - задняя нога; 14 - половой аппарат.

N. waterstoni (Subba Rao, 1971), comb.n. [Trjapitzin et al., 2004]. Information on the unsuccessful attempts to introduce $N$. myersi into Bermuda (UK) should be referred to $N$. waterstoni. Neocladia myersi is the only species in the genus whose immature stages were studied in some detail [Myers, 1930; Maple, 1947]. Male: illustrated here are the antenna (Fig. 12), hind leg (Fig. 13), and genitalia (Fig. 14).

17. Neocladia odacon (Walker, 1838), comb.n.

(Not included in the key)

Walker, 1838: 476 (Encyrtus); Noyes \& Hayat, 1984: 229 (Anagyrodes).

Australia (Tasmania). Biology unknown.

Examined was the lectotype female (BMNH) of Encyrtus odacon Walker, 1838 (designated by Noyes \& Hayat [1984]), on card labeled: 1. "Encyrtus odacon Walker", [the other side] "stood under this name in old B. M. collection. Waterhouse"; 2. "B. M. TYPE HYM. 5.1,110"; 3. [green circle] "Type". The lectotype specimen has the head detached, lacking both antennal flagella. Its poor condition does not allow for inclusion of this species in the key. Body with deep green luster, hind leg dark. Forewing with a dark band behind stigmal vein and an infuscation at apex. Metatibia moderately broadened.

\section{Neocladia orientalis (Subba Rao, 1971), comb.n.}

Subba Rao, 1971: 211-212 (Carabunia); Noyes \& Hayat, 1984: 244 (Carabunia); Mani, 1989: 991-992 (Carabunia); Hayat, 2006: 52-53 (Carabunia).

Bangladesh, from Ptyelus nebulus (Turton, 1802) (Aphrophoridae) on Hibiscus sp.; India (Karnataka); Thailand, from an unidentified froghopper (Cercopidae).

19. Neocladia perkinsi Subba Rao, 1971, stat. rev.

Subba Rao, 1971: 212-213 (Neocladia); Noyes \& Hayat, 1984: 229 (Anagyrodes).

Australia (New South Wales, Western Australia). Biology unknown.

\section{Neocladia poeta (Girault, 1928), comb.n.}

Girault, 1928a: 1 (Elijahia); Noyes \& Hayat, 1984: 244 (Carabunia); Dahms \& Gordh, 1997: 94 (Carabunia).

Australia (Western Australia). Biology unknown.

21. Neocladia punctaticeps (Girault, 1928), comb.n. Fig. 15.

Girault, 1928b: 449-450 (Anagyrodes); Noyes \& Hayat, 1984: 229 (Anagyrodes).

Philippines. Biology unknown. 


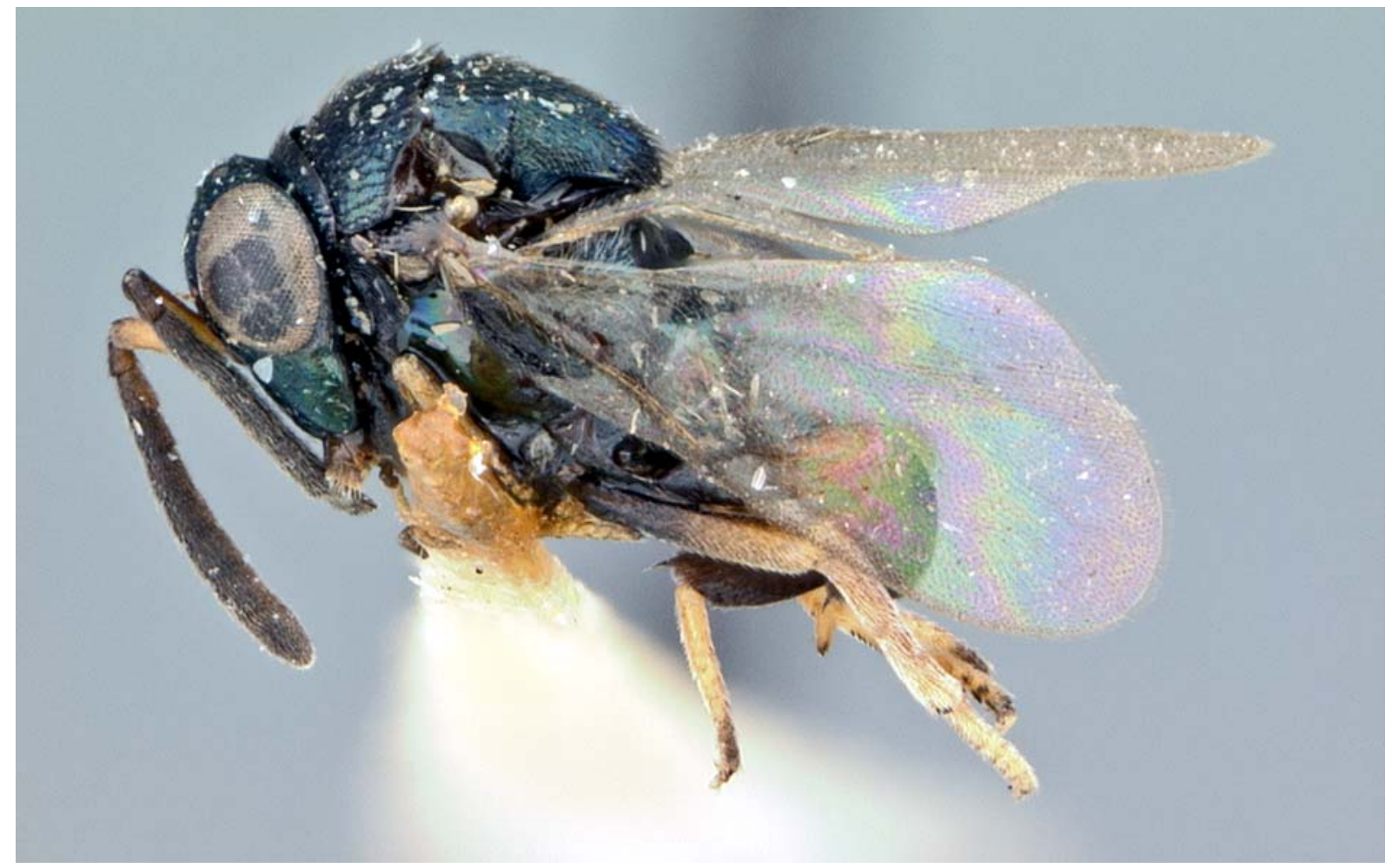

Fig. 15. Neocladia punctaticeps, female (lectotype, lateral view).

Рис. 15. Neocladia punctaticeps, самка (лектотип, сбоку).

We have examined the lectotype female (Fig. 15) in USNM, here designated to avoid ambiguity about the status of the type specimens of this species, labeled: 1. "Island of Basilan Baker"; 2. [red] "Cotype No. 41906 U.S.N.M.; 3. [in A.A. Girault's handwriting] "Anagyrodes punctaticeps Gir. Cotype $\square$ S..". Length of the lectotype about $1.8 \mathrm{~mm}$; body black, appendages brown to dark brown; wings without dark bands, at most slightly and uniformly infumate; metatibia moderately expanded. The lectotype specimen, mounted on a point, is in good condition and almost complete (only a part of the clava of one of the antennae is damaged). We could not find in USNM the second original syntype of this species [Girault, 1928b].

\section{Neocladia uttara (Hayat, 2003), comb.n.}

Hayat, 2003: 228-229 (Paracladella); Hayat, 2006: 53-54 (Paracladella).

India (Uttarakhand). Biology unknown.

\section{Neocladia waterstoni (Subba Rao, 1971),} comb.n.

Subba Rao, 1971: 209-210, 212 (Carabunia); Trjapitzin et al., 2004: 59 (Carabunia).

El Salvador; Jamaica, from Clastoptera flavidorsa Metcalf \& Bruner, 1925 (Clastopteridae) on Casuarina equisetifolia; Puerto Rico (USA), from Clastoptera sp. on coffee tree; Trinidad and Tobago. Attempts to introduce this parasitoid (as Carabunia myersi Waterston, 1928) during 19591961 from Jamaica and Puerto Rico into Bermuda against Clastoptera undulata Uhler, 1864 on Casuarina equisetifolia failed [Cock, 1985].
24. Neocladia zora (Hayat, 2003), comb.n.

Hayat, 2003: 207-208 (Carabunia); Hayat, 2006: 52-53 (Carabunia).

India (Kerala). Biology unknown.

Also several undescribed species (not included in the key) from Australia (Queensland), Colombia, India, Indonesia (Borneo), Papua New Guinea, Philippines, and Solomon Islands, listed under Anagyrodes, Carabunia, and Paracladella by Dahms \& Gordh [1997], Noyes [1980], and Noyes \& Hayat [1984].

\section{Conclusion}

This contribution is the first attempt to bring together data on the poorly known genus Neocladia as we understand it, and to prepare a partial key to females of most of its described species (species of Neocladia s. str. remain to be revised). Without any doubt, more species in this genus remain to be discovered and then properly described, while most of the already described taxa need to be thoroughly redescribed and illustrated based on fresh, well-prepared material. We have not discussed here taxonomic value of some morphological features in Neocladia, for example presence or absence of filum spinosum of linea calva on the forewing, because the material at our disposal is very limited. Further, more comprehensive, studies on Neocladia are 


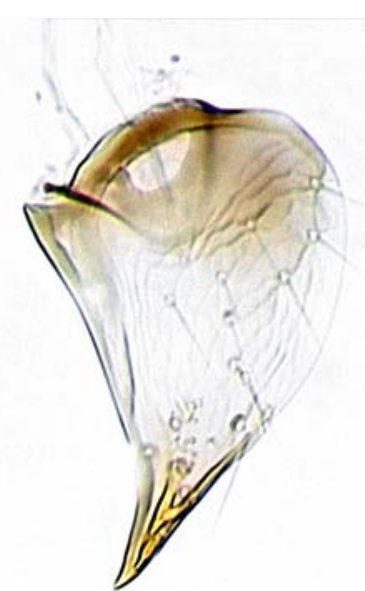

16

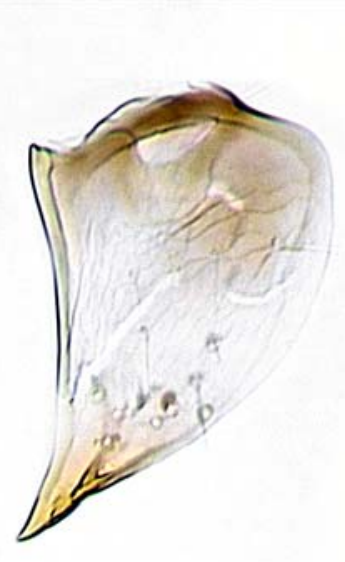

17
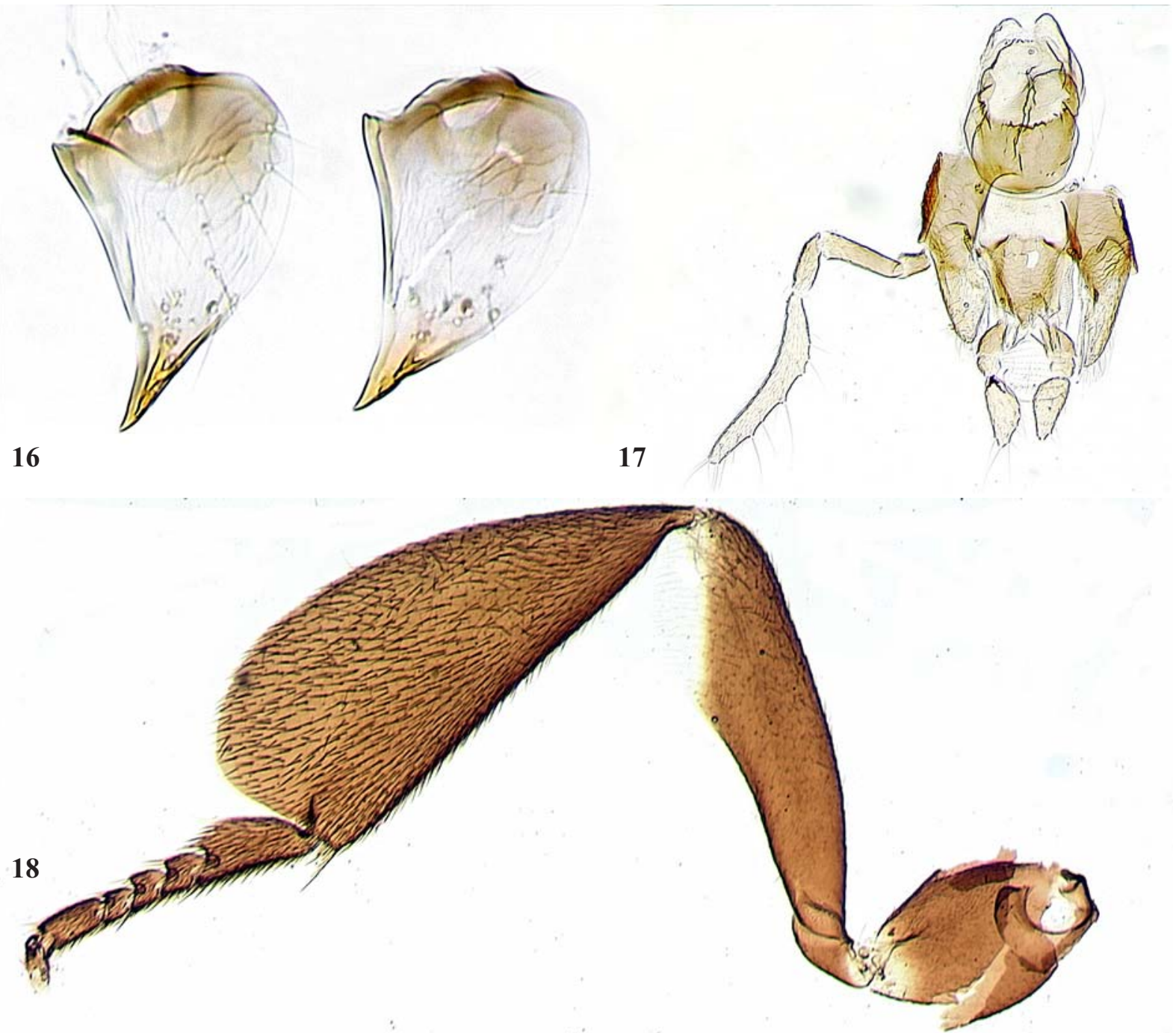

Figs 16-18. Neocladia sp. (s. str.), female [Loxton, South Australia, Australia (specimen in UCRC)]: 16 — mandibles; 17 — palpiæ 18 — hind leg.

Рис. 16-18. Neocladia sp. (s. str.), самка [Loxton, South Australia, Australia (экземпляр из UCRC)]: 16 — мандибулы; 17 - пальпы; 18 - задняя нога.

desirable because of potential importance of at least some of its species to biological control.

ACKNOWLEDGMENTS. The junior author thanks Christopher Burwell (QMBA) for the loan of specimens, and also John S. Noyes (BMNH) and Michael W. Gates (USNM) for access to the respective collections. Vladimir V. Berezovskiy (UCRC) made several excellent slide mounts of the specimens, and Natalia A. Florenskaya (St. Petersburg, Russia) made a drawing of the holotype of Neocladia korotjaevi.

\section{References}

Annecke D.P. 1965. Records and descriptions of African Encyrtidea [sic] - 3 (Hymenoptera: Chalcidoidea) // Journal of the Entomological Society of South Africa. Vol.28. No.2. P.217-229.

Cock M.T.W. (Ed.). 1985. A review of biological control of pests in the Commonwealth Caribbean and Bermuda up to 1982 // Commonwealth Institute of Biological Control, Technical Communication. No.9. P.i-vi+1-218.
Dahms E. \& Gordh G. 1997. A review of the genera of Australian Encyrtidae (Hymenoptera: Chalcidoidea) described from Australia by A. A. Girault with a checklist of included species // Memoirs on Entomology, International. Vol.9. P.i-v+1-518.

García-Jiménez J.R. 1982. Interacción entre Carabunia myersi Waterston (Hym.: Encyrtidae) y Clastoptera globosa Fowler (Hom.: Cercopidae) en la Chontalpa, Tabasco, México // Folia Entomológica Mexicana. Vol.54. P.86-87.

Girault A.A. 1915. Australian Hymenoptera Chalcidoidea - VII. The family Encyrtidae with descriptions of new genera and species // Memoirs of Queensland Museum. Vol.4. P.1-184.

Girault A.A. 1920. New genera of chalcid flies from Australia (Hymenoptera) // Insecutor Inscitiae Menstruus. Vol.8. P.142146.

Girault A.A. 1922. New chalcid flies from eastern Australia - II (Hymenoptera, Chalcididae) // Insecutor Inscitiae Menstruus. Vol.10. P.100-108.

Girault A.A. 1928a. Some new hexapods stolen from authority. Privately published, Brisbane. 4 pp.

Girault A.A. 1928b. Some new Philippine chalcid flies // Philippine Journal of Science. Vol.36. P.449-453.

Girault A.A. 1932. New pests from Australia, X. Privately published, Brisbane. 6 pp. 
Gordh G. \& Trjapitzin V.A. 1981. Taxonomic studies on the Encyrtidae with the descriptions of new species and a new genus (Hymenoptera, Chalcidoidea) // University of California Publications in Entomology. Vol.93. P.i-vi+1-64.

Hayat M. 2003. Records and descriptions of Indian Encyrtidae (Hymenoptera: Chalcidoidea)// Oriental Insects. Vol.37. P.187-259.

Hayat M. 2006. Indian Encyrtidae (Hymenoptera: Chalcidoidea) [Keys to genera and species, and a catalogue, with 1591 figures]. Privately published, Aligarh, India. i-viii+496 pp.

Mani M.S. 1989. The fauna of India and the adjacent countries. Chalcidoidea (Hymenoptera). Part 1. Agaontidae, Torymidae, Leucospididae, Chalcididae, Eurytomidae, Perilampidae, Eucharidae, Cleonymidae, Miscogasteridae, Pteromalidae, Eupelmidae and Encyrtidae// Zoological Survey of India. Calcutta, India. $\mathrm{i}-\mathrm{xxvi}+1067 \mathrm{pp}$.

Mani M.S., Dubey O.P., Kaul B.K. \& Saraswat G.G. 1973. On some Chalcidoidea from India // Memoirs of the School of Entomology, St. John's College, Agra. No.2. P.1-128.

Maple J.D. 1947. The eggs and first instar larvae of Encyrtidae and their morphological adaptations for respiration // University of California Publications in Entomology. Vol.8. No.2. P.i-viii+25122.

Myers J.C. 1930. Carabunia myersi, Watrst. (Hym., Encyrtidae), a parasite of nymphal froghoppers (Hom., Cercopidae) // Bulletin of Entomological Research. Vol.21. Pt.3. P.341-351.

Noyes J.S. 1980. A review of the genera of Neotropical Encyrtidae (Hymenoptera: Chalcidoidea) // Bulletin of the British Museum (Natural History), Entomology series. Vol.41. No.3. P.107-253.

Noyes J.S. 2010. Universal Chalcidoidea database. WWW publication, The Natural History Museum, Taxapad. http://www.nhm. ac.uk/research-curation/research/projects/chalcidoids/ index.html. Last accessed 12 January 2010.

Noyes J.S. \& Hayat M. 1984. A review of the genera of Indo-Pacific Encyrtidae (Hymenoptera: Chalcidoidea) // Bulletin of the British Museum (Natural History), Entomology series. Vol.48. No.3. P.131-395.

Perkins R.C.L. 1906. Leaf-hoppers and their natural enemies (Pt VIII. Encyrtidae, Eulophidae, Trichogrammidae) // Bulletin of the Hawaiian Sugar Planters' Association Experiment Station
(Entomology Series). No.1. Pt.8. P.239-267+3 plates on unnumbered pages.

Sharkov A.V. 1984. [Review of the chalcid genus Eugahania Mercet, 1926(Hymenoptera, Encyrtidae)]//Entomologicheskoye Obozreniye. Vol.63. Issue 4. P.817-825 [in Russian].

Subba Rao B.R. 1971. New genera and species of encyrtids (Hymenoptera: Encyrtidae) // Journal of Natural History. Vol.5. No.2. P.209-224.

Subba Rao B.R. 1973. Descriptions of two new species of Carabunia Waterston (Hymenoptera: Encyrtidae)// Oriental Insects. Vol.7. No.4. P.485-489.

Trjapitzin V.A. 1973. [Classification of parasitic Hymenoptera of the family Encyrtidae (Chalcidoidea). Part II. The subfamily Encyrtinae Walker, 1837] // Entomologicheskoye Obozreniye. Vol.52. Issue 2. P.416-429 [in Russian].

Trjapitzin V.A. 1989. [Parasitic Hymenoptera of the fam. Encyrtidae of Palaearctics]. Leningrad: Nauka Publ., Leningrad Division. 488 pp. [in Russian].

Trjapitzin V.A., Bennett F.D., Ruíz-Cancino E. \& Coronado-Blanco J.M. 2004. Annotated check-list of encyrtids (Hymenoptera: Chalcidoidea: Encyrtidae) of Central America, the West Indies and Bermuda. Universidad Autónoma de Tamaulipas, Ciudad Victoria, Mexico. 205 pp.

Trjapitzin V.A. \& Gordh G. 1978. [Review of genera of Nearctic encyrtids (Hymenoptera, Chalcidoidea, Encyrtidae). II // Entomologicheskoye Obozreniye. Vol. 57. Issue 3. P.636-653 [in Russian].

Walker F. 1838. Description of some Chalcidites discovered by C. Darwin, Esq. // Entomologist's Magazine. Vol.5. P.469-477.

Waterston J. 1928. A new encyrtid (Hym., Chalcid.) bred from Clastoptera (Hom., Cercop.) // Bulletin of Entomological Research. Vol.19. Pt.3. P.249-251.

Xu Z. \& He J. 2003. Encyrtidae // (Huang B.K. (ed.). Fauna of insects of Fujian Province of China. Fuzhou, Fujian, China: Fujian Publishing House of Science and Technology. Vol.7. P.517-537 [in Chinese], 537-543 [in English].

Zhang Y. \& Huang D. 2004. A review and an illustrated key to genera of Encyrtidae (Hymenoptera) Chalcidoidea) from China. Beijing, China: Science Press. 166 pp. 